\title{
The surprising photochemistry of sultams related to saccharin
}

\author{
Dietrich Döpp \\ Organische Chemie, Gerhard-Mercator-Universität Duisburg, D-47048 Duisburg, Germany
}

\begin{abstract}
The known light induced reactions of sulfonamides and sultams are in most (but not all) cases initiated by $\mathrm{S}-\mathrm{N}$ homolysis. Sulfur dioxide release may be a consequence of this primary process. In the author's laboratory three hitherto unexplored photoreactions of saccharin-derived sultams have been investigated: (i) a novel formal oxygen shift from sulfur to nitrogen generating up to now unknown cyclic N-hydroxysulfinamides; (ii) a condensative dimerization of 2,3-dihydro-1,2- benzoisothiazole 1,1-dioxide generating a new cleft molecule, and (iii) a facile allylic skeletal rearrangement of a pyrrolo-anellated dihydro1,2-benzoisothiazole. At least in the latter two cases an initial S - N-homolysis seems to be vital for the processes observed, whereas in the first case some ambiguity remains with respect to the first step. Scope and limitations are discussed and rationales for the conversions observed are presented, with special emphasis on structure proof by X-ray crystal structure determinations. All reactions discussed have to be treated within the wider context of current sulfonamide and sultam photochemistry.
\end{abstract}

\section{INTRODUCTION}

Some twenty years ago we studied the photodecarbonylation of 3,3-dimethyl-2,3-dihydro-indol-2(1H)one [1] and wanted to have an independent access to 2,2-dimethyl-1,2-dihydrobenzazetes. Since it had been found that 1,3-dihydrobenz[c]-2,1-isothiazoles 1a,b underwent sulfur dioxide extrusion upon $254 \mathrm{~nm}$ irradiation in solution [2] forming the benzazetine 3 (presumably via the $O$-quinonoid imine 2 ) if $\mathrm{R}^{1}=\mathrm{R}^{2}=\mathrm{H}$, while with $\mathbf{1 b}\left(\mathrm{R}^{1}=\mathrm{H}, \mathrm{R}^{2}=\mathrm{R}^{3}=\mathrm{CH}_{3}\right)$ the 2-vinylaniline $4 \mathbf{a}$ was formed, it became clear that a net hydrogen atom transfer from $\mathrm{CH}_{3}$ to the nitrogen atom took place more efficiently than ring closure. So it was not surprising that electrocyclic ring closure to the desired benzazetine failed also for 2c, the sulfur dioxide extrusion product of 1c [3] (Scheme 1).

Electronically excited N-propylsaccharin (5) on the other hand, is known to undergo (albeit more slowly than the sultams of type $\mathbf{1}$ ) a probably stepwise sulfur dioxide extrusion as well with formation of $\mathrm{N}$ propylbenzamide (6) in hydrogen donating solvents and N-propyl-2-phenylbenzamide (7) in benzene $[4,5]$ (Scheme 2).

We therefore tried sulfur dioxide extrusion from 2,3dihydro-3,3-dimethylbenzo-1,2-isothiazole 1,1-dioxide (8a), based on the reasonable assumption that $\mathrm{S}-\mathrm{N}$ homolysis, being the preferred mode of primary reaction in electronically excited open chain sulfonamides [69], was also operating in this case generating biradical $\mathbf{9}$ and (hopefully) therefrom the desired benzazetine $\mathbf{1 0}$ (Scheme 3). In this way the hydrogen shift problem associated with intermediates like $\mathbf{2} \mathbf{b}, \mathbf{c}$ should be circumvented.

\section{FORMAL OXYGEN MIGRATION}

Since the UV-spectrum of $\mathbf{8 a}$ in methanol displayed a slightly structured absorption around $263 \mathrm{~nm}(\log \varepsilon=$ $2.90)$ with a very weak tail to longer wavelengths, an irradiation with the $254 \mathrm{~nm}$ emission of the low pressure mercury arc seemed most appropriate, since irradiation with the Duran-filtered $(\lambda \geq 280 \mathrm{~nm})$ light of the high pressure mercury arc had failed to bring about any reaction.

To our surprise, however, no sulfur dioxide extrusion at all occurred. Instead, an efficient and probably stepwise rearrangement to the isomeric cyclic Nhydroxysulfinamide 11a took place [10]. Analogous observations were made later upon photolysis of compounds 8b-g [11, 12] (Scheme 4). Product quantum yields for two efficient transformations have been determined at $254 \mathrm{~nm}$ irradiation, $\mathbf{8 a} \rightarrow \mathbf{1 1 a}: \Phi_{P}=0.51$; $\mathbf{8 b} \rightarrow \mathbf{1 1 b}: \Phi_{P}=0.36$ [12].

Yields may be smaller in cases where the products happen to be oils or do not precipitate easily from the photolysis mixture so that sequential dark reactions (e.g. dehydrations) or secondary photolyses generate more complex mixtures requiring chromatographic work-up.

When the photolysis of $\mathbf{8 a}$ is monitored by UV spectroscopy, the overall absorbancy of the solution increases but this does not prevent complete conversion of the starting material. A less structured absorption of the product 11a is built up, and by the routine method developed by Mauser [13] linear $\Delta A\left(\lambda_{1}\right)$ vs. $\Delta A\left(\lambda_{2}\right)$ diagrams are obtained for four different wavelengths indicating that no intermediate would be built up which were accessible to stationary UV spectroscopic detection. Thus, if the photolysis $\mathbf{8 a} \rightarrow \mathbf{1 1 a}$ would involve 
<smiles>[R]N1c2ccccc2C([R])([R])S1(=O)=O</smiles><smiles>CCCCCCCOS(=O)(=O)O</smiles>

$1 \mathrm{a}$

$1 b$

1c

$$
\begin{aligned}
& \mathrm{R}^{1}=\mathrm{R}^{2}=\mathrm{H}, \mathrm{R}^{3}=\mathrm{CH}_{3} \\
& \mathrm{R}^{1}=\mathrm{H}, \mathrm{R}^{2}=\mathrm{R}^{3}=\mathrm{CH}_{3}
\end{aligned}
$$$$
\mathrm{R}^{1}=\mathrm{R}^{2}=\mathrm{CH}_{3}, \mathrm{R}^{3}=\mathrm{H}
$$<smiles>[R3]N=C1C=CC=CC1=C([R])[R]</smiles>

$2 a$

$2 \mathbf{b}$

2c
$2 a$
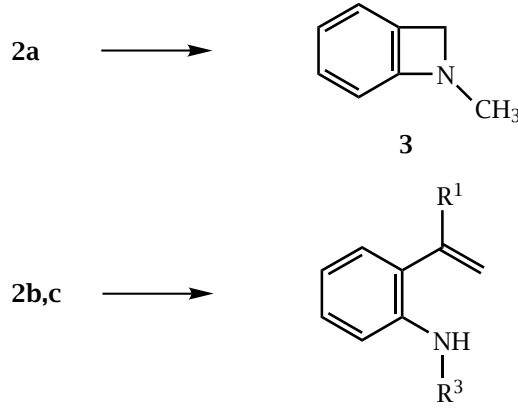

4a: $\mathrm{R}^{1}=\mathrm{H}, \mathrm{R}^{3}=\mathrm{CH}_{3}$

4b: $\mathrm{R}^{1}=\mathrm{CH}_{3}, \mathrm{R}^{3}=\mathrm{H}$

Scheme 1.<smiles>CCCN1C(=O)c2ccccc2S1(=O)=O</smiles><smiles>CCCCCC</smiles><smiles>[R]c1ccccc1C(=O)NCCC</smiles>
in EtOH or PrOH: $\quad 6 \quad(\mathrm{R}=\mathrm{H})$ in benzene: $7 \quad(\mathrm{R}=\mathrm{Ph})$

Scheme 2.

formation of an intermediate the latter would be short lived [14].

Some general remarks regarding the scope of this reaction seem to be appropriate at this stage.

1. So far, transformations like $\mathbf{8} \rightarrow \mathbf{1 1}$ have been observed only with 2,3-dihydro-1,2-benzoisothiazole 1,1-dioxides.

2. Among these, C-3 has to be substituted with at least one alkyl or aryl group, compound $\mathbf{8 j}$ $\left(\mathrm{R}^{1}=\mathrm{R}^{2}=\mathrm{X}=\mathrm{H}\right)$ does show another type of reaction [11] which will be treated further below.

3. The $\mathrm{N}-\mathrm{H}$ proton may not be substituted by alkyl groups like methyl (as in $\mathbf{8 h}$, this compound on $254 \mathrm{~nm}$ irradiation gives an intractable complex mixture of products but no 11-type product [14]) but with such groups capable of forming stable carbocations, as alkoxmethyl [12] or benzyl [15] (as in $\mathbf{8 e - g}$ ). In the case of $\mathbf{8 g}$, the isomer $\mathbf{1 1 g}$ is only a by-product besides the main ring-enlarged product 4,4-dimethyl2-phenyl-3,4-dihydro-2H-benzo-1,3-thiazine 1,1dioxide [15], and this case deserves further study. Substitution by trimethylsilyl (8i) [16] does not contribute more insight since rapid desilylation occurs coupled to a build-up of turbidity when this compound is irradiated in ace- tonitrile [12] (in methanol, a desilylation takes place in the dark [15]).

The structures of all new compounds $\mathbf{1 1}$ were supported by spectroscopic data [12] and an X-ray single crystal structural analysis of 11a [10]. Later, another $\mathrm{X}$-ray structural analysis of the photoproduct of enantiopure (R)-8c became available (see below) which lend further support to structures 11a-e,g. While there is no doubt about the correctness of the structural assignment it is suitable to briefly discuss the nature and properties of the photoproducts 11 .

These are cyclic N-hydroxysulfinamides and thereby the first representatives of a new and hitherto inaccessible functional group, namely the sulfine hydroxamic acid (albeit in a cyclic version). All attempts to prepare this functionality by reacting a sulfinyl chloride or ester with a hydroxylamine have failed so far $[17,18]$. On the other hand, $O$-alkylated sulfinyl hydroxylamines have become known but are of limited thermal stability [19]. Limited stability has also been observed for compounds 11: While the solid samples have an infinite shelf life at room temperature, they slowly but markedly revert to starting materials 8 in solution [12]. This is also true for 11e [12, 14]. The nature of this exothermic back reaction has not been elucidated yet, but depending on the acidity of the medium very likely more than one mechanism may be operating [14]. The back reaction may be monitored by ${ }^{1} \mathrm{H}$ NMR spectroscopy [14]. If an intermediate of whatever nature were involved in the back reaction it cannot be detected by this method, however.

The formal oxygen transfer from sulfur to nitrogen creates a situation in which both heteroatoms deviate in their oxidation stage from the most comfortable stage accessible: Compared to the starting materials $\mathbf{8}$, the sulfur atom in $\mathbf{1 1}$ has become reduced while the nitrogen atom has become oxidized, and the backward reaction by whatever mechanism tends to restore the 
<smiles>CC1(C)NS(=O)(=O)c2ccccc21</smiles>

$8 \mathrm{a}$<smiles>CC(C)(N)c1ccccc1[S+](=O)[O-]</smiles>

9

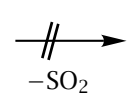

Scheme 3 .<smiles>[X]N1C([R])([R])c2ccccc2S1(=O)=O</smiles>

8

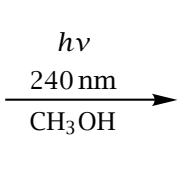<smiles>[R]N1S(=O)c2ccccc2C1([R])[R]</smiles>

11<smiles>CC1(C)Nc2ccccc21</smiles>

10

\begin{tabular}{|c|c|c|c|c|}
\hline & $\mathrm{R}^{1}$ & $\mathrm{R}^{2}$ & $\mathrm{X}$ & \\
\hline $8 \mathbf{a}$ & $\mathrm{Me}$ & $\mathrm{Me}$ & $\mathrm{H}$ & $(72 \%)$ \\
\hline $8 b$ & $\mathrm{Ph}$ & $\mathrm{Ph}$ & $\mathrm{H}$ & 11b $\quad(16 \%)$ \\
\hline $8 c$ & $\mathrm{Me}$ & $\mathrm{H}$ & $\mathrm{H}$ & 11c (Scheme 8) \\
\hline $8 d$ & $\mathrm{Ph}$ & $\mathrm{H}$ & $\mathrm{H}$ & 11d (Scheme 8) \\
\hline $8 e$ & $\mathrm{Me}$ & $\mathrm{Me}$ & $\mathrm{CH}_{2} \mathrm{OMe}$ & 11e $(51 \%)$ \\
\hline $8 f$ & $\mathrm{Me}$ & $\mathrm{Me}$ & $\mathrm{CH}_{2} \mathrm{O}-i-\mathrm{Pr}$ & (see text) \\
\hline $8 g$ & $\mathrm{Me}$ & $\mathrm{Me}$ & $\mathrm{CH}_{2} \mathrm{Ph}$ & $11 \mathrm{~g}(10 \%$, see text $)$ \\
\hline $8 \mathrm{~h}$ & $\mathrm{Me}$ & $\mathrm{Me}$ & $\mathrm{Me}$ & (see text) \\
\hline $8 i$ & $\mathrm{Me}$ & $\mathrm{Me}$ & $\mathrm{SiMe}_{3}$ & (see text) \\
\hline $8 \mathbf{j}$ & $\mathrm{H}$ & $\mathrm{H}$ & $\mathrm{H}$ & (see text) \\
\hline
\end{tabular}

Scheme 4.

thermodynamically more stable sulfonic acid amide situation characteristical of $\mathbf{8}$.

The photochemical processes involved may be envisaged as follows: Including the results obtained with the naphthoanellated starting materials 12 and 14 (Scheme 5), which behaved completely analogously to compounds 8 still requiring $254 \mathrm{~nm}$ excitation for the formation of 13 and 15, and since no quenching has ever been observed in the presence of oxygen, the reaction may well start from an upper excited singlet state.

The first events following excitation may be either (a) $\mathrm{S}-\mathrm{N}$ homolysis generating biradical $\mathbf{1 6}$ followed by $\mathrm{N}$ - O ring closure giving 17 (of hitherto unknown connectivity!) which finally rearranges to $\mathbf{1 8}$, or (b) direct transformation of 8 into 18, which in turn forms 19. If $\mathrm{X}=\mathrm{H}$, a proton shift forming $\mathbf{1 1 a}-\mathbf{d}$ is most plausible (Scheme 6). In the case of starting materials $\mathbf{8 e - g}$, the alkyl group on $\mathrm{N}$ would have to be taken over by the migrated oxygen atom as well.

Photolysis of starting material 8f $(\mathrm{X}=2-\mathrm{O}-\boldsymbol{i}-\mathrm{Pr})$ in methanol is associated with an exchange of the isopropoxy group against methoxy resulting in formation of 11e instead of 11f. A dark reaction exchanging the alkoxy group in methanol cannot be responsible for this<smiles>CC1(C)NS(=O)(=O)c2ccc3ccccc3c21</smiles>

12<smiles>CC1(C)NS(=O)(=O)c2c1ccc1ccccc21</smiles>

14
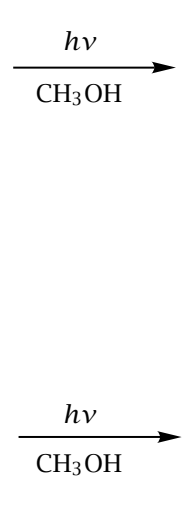

Scheme 5.

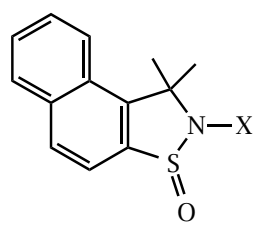

13a: $\mathrm{X}=\mathrm{OH}, 23 \%$ 13b: $X=H, 6 \%$<smiles>CC1(C)c2ccc3ccccc3c2S(=O)N1O</smiles>

15 result, as had been tested independently [14], so the exchange has to be coupled to the photorearrangement. A rationale has been suggested in Scheme 7.

It is assumed that 2-propoxide is released from $19 f$ while the $\mathrm{N}$-oxide oxygen attacks the methylene carbon forming intermediate 20 which undergoes $\mathrm{CH}_{2}-\mathrm{N}$ heterolysis by solvent attack forming 11e. An analogous process in 19e would, of course, remain undetected under the conditions used.

The photoisomerizations of $\mathbf{8 c}, \mathbf{d}$ to $\mathbf{1 1 c}, \mathbf{d}$ show a moderate stereoselectivity. By ${ }^{1} \mathrm{H}$ NMR integration the ratio of the two diastereomers (anti- and $s y n$-) formed upon photolysis of $\mathbf{8 c} \mathbf{( 8 d}$ ) is 72:28 (69:31). In both cases the major (and thermodynamically more stable) isomer is the one with the sulfoxide O-atom anti-oriented to the substituent (Me, $\mathrm{Ph}$ ) on $\mathrm{C}-3$. This is both made likely by inspection of models and firmly corroborated by the single crystal X-ray structure analysis of the product $(1 R, 2 R, 3 R)-\mathbf{1 1 c}$ from $(R)-8 \mathrm{c}$ [20] under the usual conditions. The same orientation and (relative) configuration of anti- and syn-11d is proposed by analogy (Scheme 8).

Pyramidalization at sulfur and (at least in the solid state) also on nitrogen is reflected in the ${ }^{1} \mathrm{H}$ NMR data of the products. A pyramidal array around the $\mathrm{N}$-atom may well be prevailing also in solution since there is strong indication that electron attracting atoms or groups being not conjugated to the $\mathrm{N}$ lone pair stabilize 


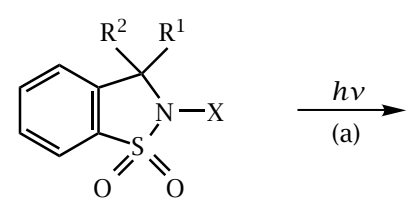<smiles>[X][NH+]([X])C([R])([R])c1ccccc1S(C)(=O)=O</smiles><smiles>[Y]N1OS(=O)c2ccccc2C1([R])[R]</smiles>

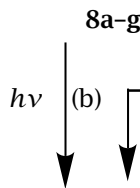

16a-g

17a-g<smiles>[R]C1([R])c2ccccc2[Si]2([O-])O[N+]12[Y]</smiles><smiles>[R]C1([R])c2ccccc2S(=O)[N+]1([X])[O-]</smiles><smiles>CCCCC</smiles><smiles>[R]ON1S(=O)c2ccccc2C1([R])[R]</smiles>

18a-g

19a-g

11a-e,g

Scheme 6.

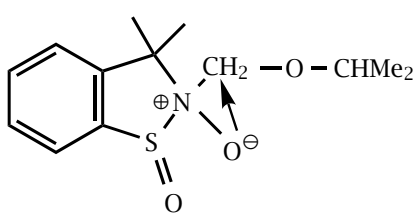

$19 f$

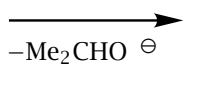

hv $\stackrel{\mathrm{CH}_{3} \mathrm{OH}}{\longrightarrow}$<smiles>[R]C1(C)NS(=O)(=O)c2ccccc21</smiles>

$\mathrm{R}=\mathrm{Me}: \quad \mathbf{8 c}$

$\mathrm{R}=\mathrm{Ph}: \quad \mathbf{8 d}$<smiles>C[C@H]1NS(=O)(=O)c2ccccc21</smiles><smiles>C=C</smiles>

$(R)-8 \mathrm{c}$<smiles>[R][C@]1([2H])c2ccccc2[Se](=O)N1O</smiles>

anti-11c (> 14\%)

anti-11d (> 16\%)<smiles>C[C@H]1c2ccccc2[Se](=O)N1O</smiles>

$(1 R, 2 R, 3 R)-11 \mathrm{c}$<smiles>[R][C@]1([2H])c2ccccc2[Se](=O)N1O</smiles>

syn-11c

syn-11d

Scheme 8 . 
<smiles>O=S1(=O)NCc2ccccc21</smiles><smiles>CCCC</smiles>

$8 \mathbf{j}$<smiles>O=S1(O)(O)NC=C2C=CC=CC21</smiles>

21

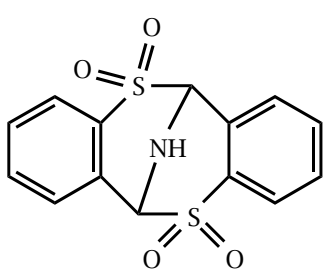

22

Scheme 9 .

a pyramidal configuration at the $\mathrm{N}$ atom in heterocycles [21-23].

At present, the following problems are being tackled in our group:

1. Secondary photolysis. Preliminary results indicate that at least in alcoholic solvents overirradiation of starting materials $\mathbf{8}$ or irradiation of single isolated products $\mathbf{1 1}$ result in deoxygenation of the latter (see formation of product $\mathbf{1 3 b}$ in Scheme 5 and other examples [14, 24]). Either one of the oxygen atoms in $\mathbf{1 1}$ may be lost initially [25], the final stable product always is a cyclic sulfinamide like $\mathbf{1 3 b}$. This problem is closely related to conventional reduction of compounds $\mathbf{1 1}$.

2. Mechanism of the backward reaction. Upon treatment of an acetonitrile solution of 11a with acid $\left(10^{-3}-10^{-4} \mathrm{M}\right)$ quickly produces a brown colouring which slowly fades giving way to the formation of 8a [14]. Another possibility of monitoring the back reaction $\mathbf{1 1} \rightarrow \mathbf{8}$ is following the change in rotation of $(1 R, 2 R, 3 R)-\mathbf{1 1}$, the initial value of which (extrapolated to zero time in solution) is $[\alpha]_{D}^{20}=-2,3^{\circ}(c=0.76$, methanol $)$ [12] to $[\alpha]_{D}^{20}=+28^{\circ}(c=1.15$, chloroform $)$ which is the reported [20] specific rotation of $(R)-8 \mathrm{c}$.

\section{A NEW CLEFT MOLECULE}

As already mentioned, compound $\mathbf{8 j}$ does not show any oxygen atom transfer as do $\mathbf{8 a - g}$. Instead, also under $254 \mathrm{~nm}$ irradiation in methanol, $8 \mathbf{j}$ gave a crystalline material representing a compound formed from two molecules of starting material with loss of one molecule of ammonia $[11,26]$. Since upon excitation the deuterium label of [3,3- $\left.d_{2}\right]-\mathbf{8 j}$ was exchanged quickly against hydrogen atoms [27] it seemed justified to assume that a process close to a photoenolization led to intermediate 21 which could dimerize and release ammonia to form 22 [26]. The latter compound has been fully characterized by spectroscopic data and by a single crystal X-ray structural analysis [28] showing (aside of the $\mathrm{N}-\mathrm{H}$ bond) a symmetry close to $\mathrm{C}_{2}$ and the two benzo rings folded towards each other and forming a cleft. The gross structure is somewhat reminiscent to Tröger's base (Scheme 9).

It should be clearly emphasized that

1. the course of the reaction ultimately leading to 22 so far is entirely speculative and awaits further clarification, and

2. dimerizations of diene-type compounds leading to eight-membered rings are not unusual and have been observed with various precursors [29].

\section{AN ALLYLIC SKELETAL REARRANGEMENT}

Dihydropyrrolo[1,2-b][1,2]benzoisothiazole 5,5-dioxides 23a-c [30] and 23d,e [31] may be easily prepared from saccharin. Photolysis $(254 \mathrm{~nm})$ of 23a-d,e in acetonitrile results in a clean rearrangement into the isomeric 2,3-dihydro[1]benzothieno[3,2-b]pyrrole 4,4-dioxides 25a-c,e [31]. Again, the structures of the new products have been delineated from their spectral data (especially the consequences of build-up of a stereogenic center at C3a should be mentioned) and firmly corroborated by an X-ray single crystal structural analysis for compound 24b [31].

The following rationale for the conversion $23 \rightarrow 25$ has been proposed: Light induced S - N homolysis generates the resonance-stabilized biradical 24 which uses its option to recyclize via $\mathrm{C}-\mathrm{S}$ bond formation. In this way, a $\mathrm{C}=\mathrm{N}$ double bond and a new $\mathrm{C}-\mathrm{S}$ single bond are erected at the expense of a $\mathrm{S}-\mathrm{N}$ and $\mathrm{C}=\mathrm{C}$ bond. The UV-spectrum of 23c (being representative for 23af) in acetonitrile displays two distinct but structureless bands at $\lambda_{\max }=324 \mathrm{~nm}(\log \varepsilon=4.0$, with a tail to about $400 \mathrm{~nm})$ and $\lambda_{\max }=250 \mathrm{~nm}(\log \varepsilon=3.9)$. It had been found that irradiation into the short wavelength band of starting materials 23 most efficiently caused reaction and oxygen showed no effect, thus a start from an upper singlet state seems most plausible (Scheme 10).

Two details are especially noteworthy:

1. The comparatively long time of irradiation required to effect a $22 \%$ yield of 25 e may be rationalized not only by the reduced electronwithdrawing effect of the toluamide group but also by steric constraints compared to the more 
<smiles>[R]C1=C2c3ccccc3S(=O)(=O)N2CC1</smiles>

23

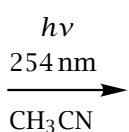

$\mathrm{CH}_{3} \mathrm{CN}$<smiles>[R]C1=C(c2ccccc2S(=O)(=O)O)N=CC1</smiles>

$\begin{array}{cc} & \\ 25 a & 91 \% \\ 25 b & 86 \% \\ 25 c & 88 \% \\ - & \\ 25 e & 22 \% \\ 25 f & \end{array}$

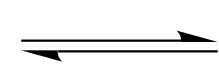

24<smiles>[R]C1=C(c2ccccc2[S+](=O)[O-])N=CC1</smiles><smiles></smiles>

25

Scheme 10.

electron demanding properties and smaller size of the acceptors present in 23a-c.

2. When the ester $23 f$ formed with (-)-menthol is subjected to irradiation under otherwise the same conditions, the rearrangement shows high diastereoselectivity: Only one of the two diastereomers (with respect to absolute configuration at C-3a) of $\mathbf{2 5 f}$ is formed [15], and a single-crystal $\mathrm{X}$-ray structural analysis will allow to unravel the sense of chirality at C-3a.

A ring transformation which at first glance looks related to that reported above is seen in the rearrangement of a benzo-1,2-isothiazolo-[2,3-a]-8bH-azete into a 2a,7b-dihydro-benzothieno[3,2-b]azete as a consequence of the $[2+2]$-photocycloaddition of ethyl 2butynoate to a 1,2-benzoisothiazole [32] which, however, has been interpreted by the authors in a different way. A related $\mathrm{S}-\mathrm{N}$ homolysis is encountered in the photolysis of 2-sulfon-amidocyclohexen-2-ones [9] where a sulfonyl/cyclohexenaminyl radical pair is formed. In this case, however, release of sulfur dioxide is faster than recombination at the 1-azaallylic carbon atom C-3.

\section{CONTEXTUAL AND CONCLUDING REMARKS}

In this account coverage has been largely restricted to light induced conversions of fivemembered benzoanellated sultams studied in the author's laboratory. These cases, however, have to be seen in a wider context. A good deal of inspiration did come from the pioneering work on the photoextrusion of sulfur dioxide from sufones [33, 34] and the elucidation of the role of singlet and triplet excited states and biradicals therein. Of relevance and certainly in future also of influence on the work reported will be the aspect of electron-transfer mediation of light induced $\mathrm{S}-\mathrm{N}$ homolysis in sulfonamides [35]. Intramolecular electron transfer may be responsible for the $\mathrm{N}-\mathrm{C}$ mode of ring cleavage in sulforhodamines [36] adding to the various modes of reactivity to be encountered in sultam photochemistry.

Attention should also to be drawn to related work, as the classical studies on sulfur dioxide extrusion in $\mathrm{N}$-propyl saccharin as already mentioned [4,5], and the photoinduced homolyses of the O-alkyl bonds in pseudosaccharin ethers $[37,38]$. It should be pointed out also that $\mathrm{S}-\mathrm{N}$ homolysis, albeit a central issue in sultam photochemistry, is not restricted to the $\mathrm{SO}_{2}-\mathrm{N}$ moiety and may be found in non-dioxide systems as well, opening a way to interesting ring enlargements [39].

The photoreactivity of six-membered sultams is likewise attractive, as is demonstrated by the interest in the photochemistry of piroxicam [40] but also of other sixmembered sultams with various biological activities [41].

Since also many other five- and six-membered benzoanellated sultams have biological activity [42, 43], there is a natural interest in their photochemistry, and the availability of synthetic procedures $[42,44]$ will be helpful in preparing model substances.

\section{ACKNOWLEDGEMENT}

The work from the author's laboratory has been generously supported by Alexander-von-Humboldt- 
Foundation, Fonds der Chemischen Industrie, DAAD and the University of Duisburg. The author is also indebted to BAYER AG for a generous gift of saccharin.

\section{REFERENCES}

[1] D. Döpp and H. Weiler, Chem. Ber. 112 (1979), 3950.

[2] M. Lancaster and D. J. H. Smith, J. Chem. Soc., Chem. Commun. (1980), 471.

[3] D. Döpp and P. Lauterfeld, unpublished.

[4] I. Ono, S. Sato, K. Fukuda, and T. Inayoshi, Bull. Chem. Soc. Jpn. 70 (1997), 2051.

[5] N. Kamigata, T. Saegusa, S. Fujie, and M. Kobayashi, Chem. Lett. (1979), 9.

[6] W. M. Horspool, Photochemistry and Radiation Chemistry, in The Chemistry of Sulphonic Acids, Esters and Their Derivatives, S. Patai and Z. Rappoport (eds.), J. Wiley \& Sons, New York, 1991, p. 501, and refs. cited therein.

[7] J. A. Pincock, The Photochemistry of Sulfonamides and Sulfenamides, CRC-Handbook of Organic Photochemistry and Photobiology, W. M. Horspool and P.-S. Song (eds.), CRC Press, Boca Raton, 1995, and refs. cited therein.

[8] a) F. Golpashin, B. Weiss, and H. Dürr, Arch. Pharm. (Weinheim) 317 (1984), 906.

b) B. Weiss, H. Dürr, and H.-J. Haas, Angew. Chem. 92 (1980), 647; Angew. Chem. Int. Ed. Engl. 19, 648.

[9] a) J. C. Arnould, J. Cossy, and J. P. Pete, Tetrahedron Lett. (1976), 3912.

b) J. A. Pincock and A. Jürgens, Tetrahedron Lett. (1979), 1029.

[10] D. Döpp, C. Krüger, P. Lauterfeld, and E. Raabe, Angew. Chem. 99 (1987), 142; Angew. Chem. Int. Ed. Engl. 26, 146.

[11] D. Döpp, P. Lauterfeld, M. Schneider, D. Schneider, and U. Seidel, Phosphorus, Sulfur, Silicon Relat. Elem. 95/96 (1994), 481.

[12] D. Döpp, P. Lauterfeld, M. Schneider, D. Schneider, G. Henkel, Y. Abd el Sayed Issac, and I. Elghamry, submitted for publication.

[13] a) H. Mauser, Z. Naturforsch. 23b (1968), 1025. b) H. D. Scharf and J. Fleischhauser, Methoden der Organischen Chemie, E. Müller (ed.), $4^{\text {th }}$ edition, Vol. IV/5a pt 1 (Houben-Weyl-Müller, Thieme, Stuttgart) 1975, p. 21.

[14] a) P. Lauterfeld, doctoral thesis, University of Duisburg, 1987.

b) D. Döpp and P. Lauterfeld, unpublished.

[15] D. Döpp and I. Elghamry, unpublished.

[16] E. Differding and R. W. Lang, Helv. Chim. Acta 72 (1989), 1248.

[17] A. F. Whalen and L. W. Jones, J. Am. Chem. Soc. 47 (1925), 1356.

[18] V. F. Adrianov, A. Y. Kaminskii, S. S. Gitis,
A. V. Ivanov, T. M. Beregovykh, and N. I. Faingold, Reakts. Sposobn. Org. Soedin. 12 (1975), 91; Chem. Abstr. 84 (1976), 179449 n.

[19] a) G. Zinner and W. Ritter, Arch. Pharm. (Weinheim) 296 (1963), 681.

b) K. Hovius and J. B. F. N. Engberts, Tetrahedron Lett. (1972), 181.

c) T. J. Maricich, R. A. Jourdenais, and T. A. Albright, J. Am. Chem. Soc. 95 (1973), 5831.

[20] W. Oppolzer, M. Wills, C. Starkemann, and G. Bernardelli, Tetrahedron Lett. 31 (1990), 4117.

[21] J. M. Lehn and J. Wagner, Tetrahedron 26 (1970), 4227.

[22] T. A. J. W. Wajer, H. W. Geluk, J. F. B. N. Engberts, and T. J. de Boer, Rec. Trav. Chim. Pays-Bas 89 (1970), 696.

[23] H. Teeninga and J. B. F. N. Engberts, J. Org. Chem. 48 (1983), 537.

[24] D. Schneider, doctoral thesis, University of Duisburg, 1994.

[25] H. Böshagen, W. Geiger, and H. Medenwald, Chem. Ber. 103 (1970), 3166.

[26] M. Schneider, doctoral thesis, University of Duisburg, 1991.

[27] D. Döpp and U. Seidel, unpublished.

[28] D. Döpp, M. Schneider, and G. Henkel, to be published.

[29] a) W. R. Roth, M. Biermann, H. Dekker, R. Jochems, C. Mosselman, and H. Hermann, Chem. Ber. 111 (1978), 3892.

b) I. Bitter, L. Szócs, and L. Töke, Acta Chim. Acad. Sci. Hung. 197 (1981), 2171.

c) M. Pišová and M. Soucek, Coll. Czech. Chem. Commun. 47 (1982), 838.

d) L. Field and C. Lee, J. Org. Chem. 55 (1990), 2558.

e) M. Schmidt, H. Meier, and S. A. Saleh, J. Heterocycl. Chem. 28 (1991), 573.

f) L. E. Brieaddy and K. H. Donaldson, J. Heterocycl. Chem. 32 (1995), 1683.

g) N. Fujiwara, Y. Ueda, and N. Ohashi, Bioorg. Med. Chem. Lett. 6 (1996), 743.

h) D. Groeschl and H. Meier, J. Heterocycl. Chem. 33 (1996), 1727.

i) K. Mitra, M. E. Pohl, L. R. MacGillivray, C. L. Barnes, and K. S. Gates, J. Org. Chem. 62 (1997), 9361.

j) I. W. J. Still, R. Natividad-Preyra, and F. D. Toste, Can. J. Chem. 77 (1999), 113.

k) M. Harmata and M. Kahraman, J. Org. Chem. 64 (1999), 4949.

l) M. Pulst, M. Wecks, U. Eilitz, and D. Greif, Synthesis (1999), 787.

m) M. C. Kimber, A. C. Try, L. Painter, M. M. Harding, and P. Turner, J. Org. Chem. 65 (2000), 3042.

[30] a) M. Blanco, I. A. Perillo, and C. Schapira, J. Heterocycl. Chem. 32 (1995), 145. 
b) C. Schapira, G. Lorenzo, and I. A. Perillo, An. Quim. (Real Soc. Espanola Quim.) 88 (1992), 265.

[31] I. Elghamry, D. Döpp, and G. Henkel, submitted.

[32] M. Sindler-Kulyk and D. C. Neckers, J. Org. Chem. 48 (1983), 1275.

[33] R. S. Givens, B. Hrinczenko, J. H.-S. Liu, B. Matuszewski, and J. Tholen-Collison, J. Am. Chem. Soc. 106 (1984), 1779, and references cited therein.

[34] I. R. Gould, C. Tung, N. J. Turro, R. S. Givens, and B. Matuszewski, J. Am. Chem. Soc. 106 (1984), 1789.

[35] a) T. Hamada, A. Nishida, Y. Matsumoto, and O. Yonemitsu, J. Am. Chem. Soc. 102 (1980), 3978. b) T. Hamada, A. Nishida, and O. Yonemitsu, J. Am. Chem. Soc. 108 (1986), 140.

c) T. Hamada, A. Nishida, and O. Yonemitsu, Tetrahedron Lett. 30 (1989), 4241.

d) J. F. Art, J. P. Kestmont, and J. P. Soumillion, Tetrahedron Lett. 32 (1991), 1425.

e) R. R. Hill, G. E. Jeffs, D. R. Roberts, and S. A. Wood, Chem. Commun. (1999), 1735.

[36] a) K.-H. Knauer and R. Gleiter, Angew. Chem. 89 (1977), 116; Angew. Chem. Int. Ed. Engl. 16, 113. b) J. E. T. Corrie, private communication.

[37] U. C. Yoon, S. J. Lee, J. H. Kim, and H. J. Kim, J. Photosci. 2 (1995), 77.

[38] U. C. Yoon, J. H. Kim, S. J. Lee, S. W. Oh, and W. W. Park, J. Korean Chem. Soc. 41 (1997), 666.

[39] a) N. Kamigata, S. Hashimoto, M. Kobayashi, and H. Nakanishi, Bull. Chem. Soc. Jpn. 58 (1985), 3131. b) N. Kamigata, H. Iizuka, and M. Kobayashi, Bull.
Chem. Soc. Jpn. 59 (1986), 1601.

c) N. Kamigata, H. Iizuka, and M. Kobayashi, Heterocycles 24 (1986), 919.

[40] a) I. Kochevar, W. L. Morrison, J. L. Lamm, D. J. McAuliffe, A. Western, and A. F. Hood, Arch. Dermatol. 122 (1986), 1283.

b) M. Yoon, H. N. Choi, H. W. Kwon, and K. H. Park, Bull. Korean Chem. Soc. 9 (1988), 171.

c) M. Yoon and Y. H. Kim, Bull. Korean Chem. Soc. 10 (1989), 434.

d) R. Becker, S. Chakravorti, and M. Yoon, Photochem. Photobiol. 51 (1990), 151.

e) J. Martins, M. M. Sena, R. J. Poppi, and F. B. T. Pessine, Appl. Spectrosc. 53 (1999), 510.

[41] a) S. R. Tamat and D. E. Moore, J. Pharm. Sci. 72 (1983), 180.

b) F. Catalina, J. L. Mateo, R. Sastre, A. Herero, C. Ochoa, and N. S. Allen, J. Photochem. Photobiol. A: Chem. 53 (1990), 293.

c) K. Hustert and M. Mansour, Tetrahedron Lett. 30 (1989), 6159.

d) C. V. Kumar, K. R. Gopidas, K. Bhattacharya, P. K. Das, and M. V. George, J. Org. Chem. 51 (1986), 1967.

[42] B. Schulze and K. Illgen, J. Prakt. Chem. 339 (1997), 1; and refs. cited therein.

[43] D. C. Martyn, M. Moore, and A. D. Abell, Curr. Pharm. Design. 405 (1999), and refs. cited therein.

[44] J. M. Villalgordo, A. Linden, and H. Heimgartner, Helv. Chim. Acta 75 (1992), 2270. 


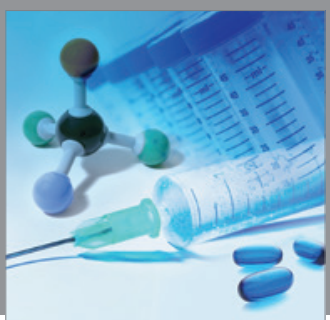

International Journal of

Medicinal Chemistry

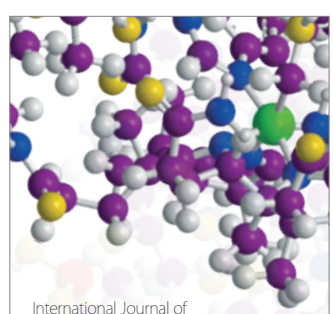

Carbohydrate Chemistry

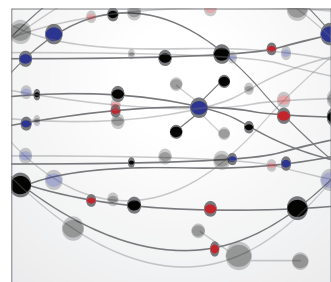

The Scientific World Journal
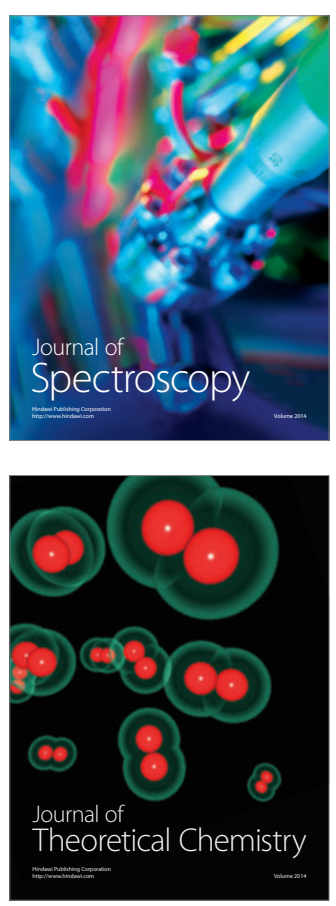
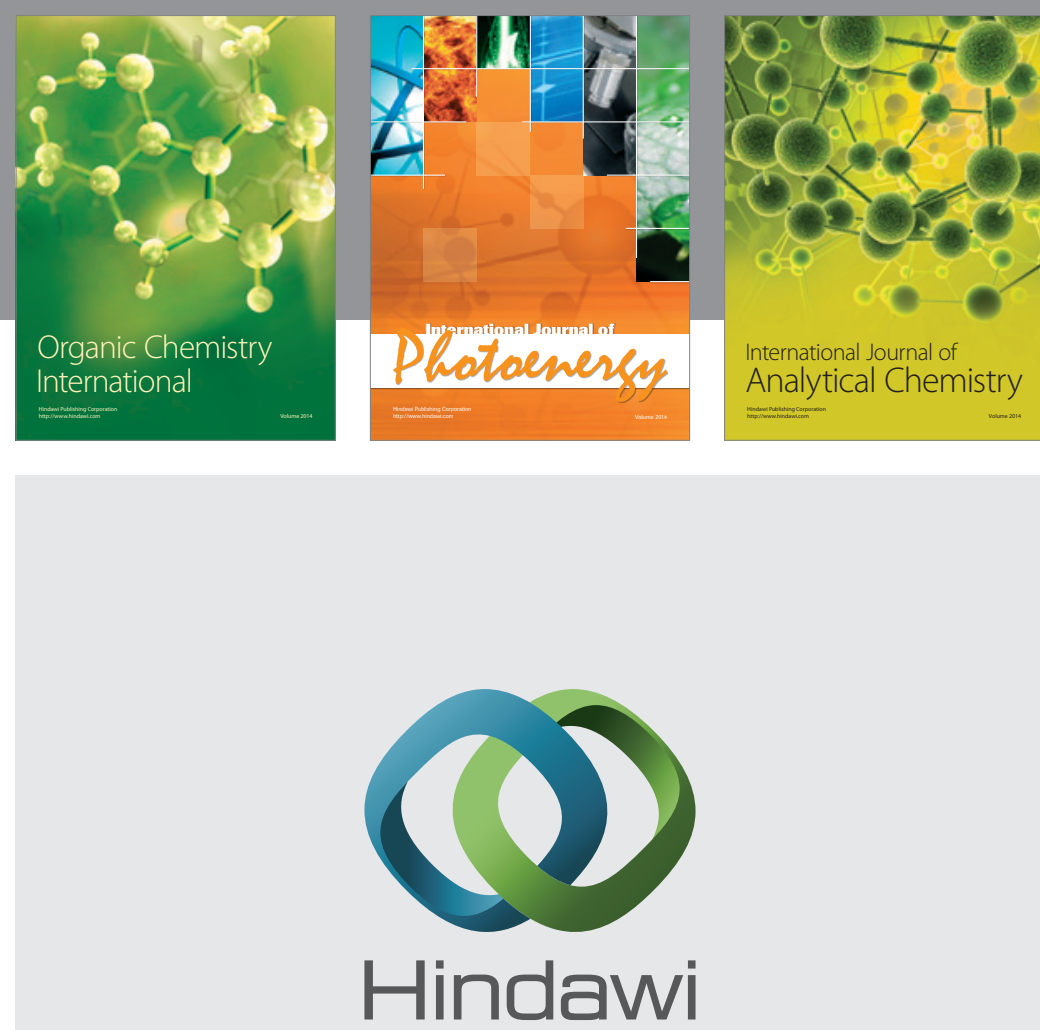

Submit your manuscripts at

http://www.hindawi.com
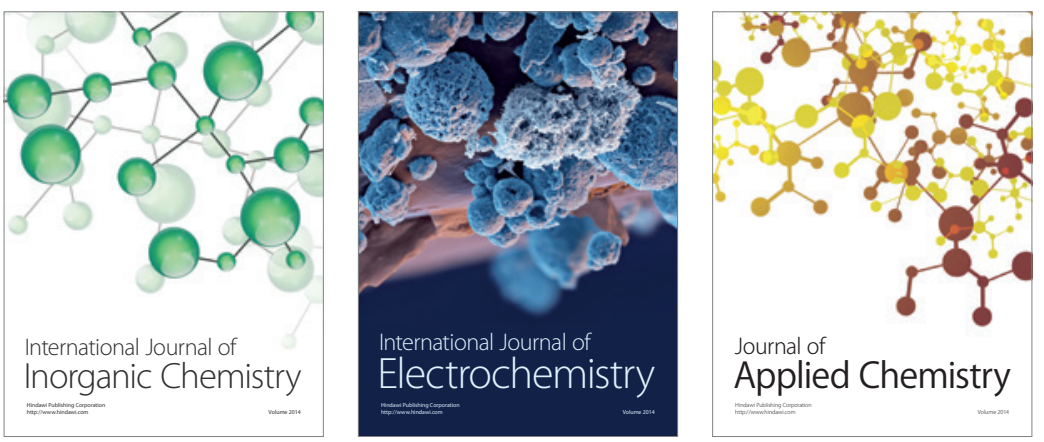

Journal of

Applied Chemistry
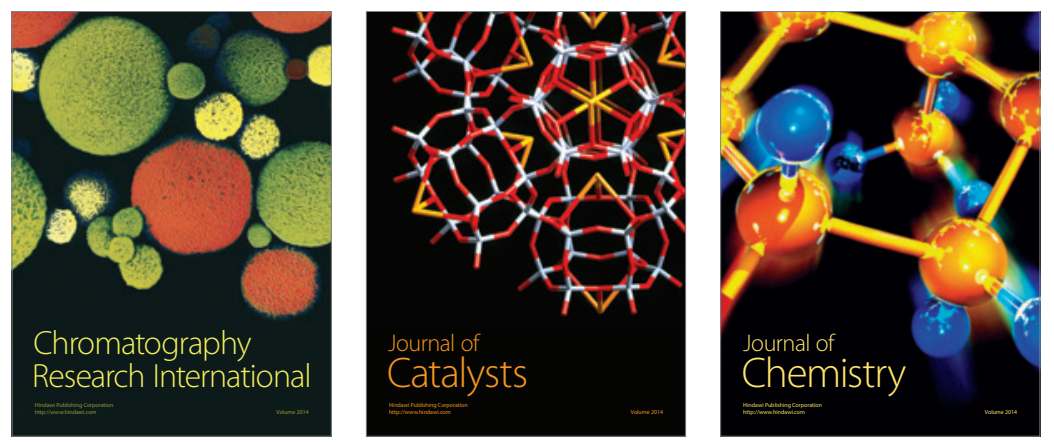
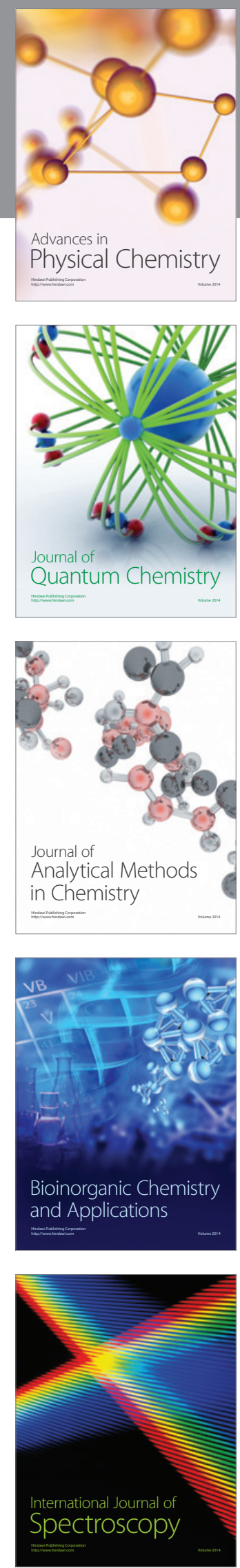